\title{
Retraction Notice to: Nuclear Matrix Protein 22 in Voided Urine Cytology Efficacy in Risk Stratification for Carcinoma of Bladder
}

\author{
Editorial Office
}

This retracts the article "Nuclear Matrix Protein 22 in Voided Urine Cytology Efficacy in Risk Stratification for Carcinoma of Bladder", by Monica Sankhwar et al, published in Vol. 4, No. 3,
2013, p151-157, doi: http://dx.doi.org/10.4021/wjon677w.

This article is retracted by the Editorial Office of World Journal of Oncology, due to the existing plagiarism in the article.

Manuscript submitted February 1, 2022, accepted February 2, 2022

Published online February 28, 2022

World Journal of Oncology Editorial Office. Email: editor@wjon.org

doi: https://doi.org/10.14740/wjon677wr 